\title{
MAIZE GROWTH, YIELD AND SOIL NUTRIENT CHANGES WITH N-ENRICHED ORGANIC FERTILIZERS
}

\author{
OT Ayoola ${ }^{1}$ and EA Makinde ${ }^{2 *}$
}

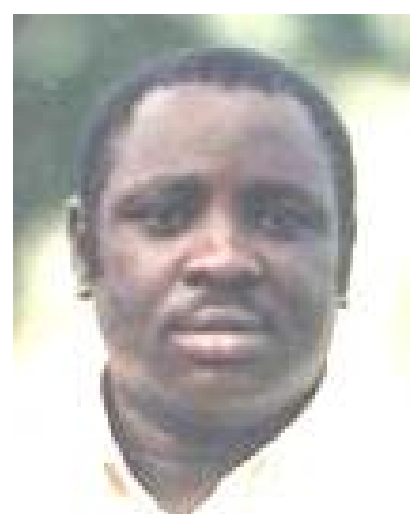

Eyitayo Makinde

*Corresponding author. Email: eamakinde@yahoo.com

${ }^{1}$ Farming Systems Research \& Extension Programme, Institute of Agricultural Research and Training, Obafemi Awolowo University, P.M.B 5029. Moor Plantation, Ibadan, Nigeria.

${ }^{2}$ Federal College of Agriculture, I.A.R \& T, P.M.B 5029.Moor Plantation, Ibadan, Nigeria 


\section{ABSTRACT}

Experiments were conducted in the growing seasons of 2005 and 2006 at Ibadan, Nigeria, in the degraded tropical rain forest zone to assess the growth and yield of maize with Nitrogen-enriched organic fertilizer made from municipal waste and cow dung (2.5 $\mathrm{tha}^{-1}$ Pacesetter fertilizer $+100 \mathrm{~kg} \mathrm{ha}^{-1}$ urea) and also with Nitrogen-fortified poultry manure. Their performance was compared with those of inorganic NPK fertilizer and no fertilizer control. Maize growth was significantly $(\mathrm{P}=0.05)$ affected by an enrichment of the organic manures. They had plants comparable in height with inorganic fertilizer application. At harvest, plants treated with fortified poultry manure were about $259 \mathrm{~cm}$ tall while those treated with fortified Pacesetter fertilizer and the plants treated with inorganic fertilizer were about $253 \mathrm{~cm}$ tall. Average plant leaf areas were similar with the fortified fertilizers and with inorganic fertilization. Length of days taken to achieve 50\% tasselling was also reduced with fertilization. Inorganic fertilizer application gave plants that achieved $50 \%$ tasselling in 50days while fortified poultry manured - plants took 52days and the fortified Pacesetter fertilizer treated plants took 53days. Fertilization of maize gave significantly $(\mathrm{P}=0.05)$ higher seed yields. Fortified poultry manure gave an average yield of $3.97 \mathrm{t} \mathrm{ha}^{-1}$ while fortified Pacesetter fertilizer had an average of $3.78 \mathrm{t} \mathrm{ha}^{-1}$.Inorganic fertilizer gave a yield of $3.70 \mathrm{t} \mathrm{ha}^{-1}$ while a significantly lower yield of $2.48 \mathrm{t} \mathrm{ha}^{-1}$ was given by the unfertilized plants. Maize growth and yield from the enriched organic manures were comparable with inorganic fertilizer, indicating the potentials of the use of fortified organic manures as alternatives to inorganic fertilizers. Poultry manure required lesser $\mathrm{N}$-fortification to give comparable seed yields as cow dung. Although both organic manures increased the soil $\mathrm{N}$ and $\mathrm{P}$, poultry manure gave higher values while the soil $\mathrm{K}, \mathrm{Ca}$ and $\mathrm{Mg}$ contents were more increased with the cow dung than poultry manure. Poultry manure, fortified with $100 \mathrm{~kg}$ Urea can be applied at $2.5 \mathrm{t} \mathrm{ha}^{-1}$ to cultivate maize. It gives a comparable yield as inorganic fertilizer and increases the soil $\mathrm{N}$ and P.

Key words: Maize, organic manures, soil nutrients. 


\section{INTRODUCTION}

Maintenance of high crop yields under intensive cultivation is possible only through the use of fertilizers. The use of inorganic fertilizers has not been helpful as it is associated with increased soil acidity and nutrient imbalance [1]. Inorganic fertilizers are usually not available and are always rather expensive for the low-income, smallscale farmers. Organic manures, such as cow dung; poultry manure and crop residues can be used as an alternative for the inorganic fertilizers. The need to use renewable forms of energy has revived the use of organic fertilizers worldwide. Nutrients contained in organic manures are released more slowly and are stored for a longer time in the soil, thereby ensuring a long residual effect [2], supporting better root development, leading to higher crop yields [3].Improvement of environmental conditions and public health as well as the need to reduce costs of fertilizing crops are also important reasons for advocating increased use of organic materials [4].The soil fertility status is improved by activating the soil microbial biomass [5].To meet crops' nutrient supply, organic fertilizers are, however, required in rather large quantities. Application of organic manures sustains cropping systems through better nutrient recycling [6].Application of organic manures plays a direct role in plant growth as a source of all necessary macro and micronutrients in available forms during mineralization, thereby improving both the physical and the biological properties of the soil[7].Organic manures decompose to give humus which plays an important role in the chemical behaviour of several metals in soils through the flavonic and humic acid contents, which have the ability to retain the metals in complex and chelate forms[7].Organic manures also improve the water holding capacity of the soil; improve the soil structure and the soil aeration[5]. The benefits derivable from the use of organic materials have however not been fully utilized in the humid tropics. Supply of nutrients from the organic materials can be complemented by enriching them with inorganic nutrients that will be released fast and utilized by crops to compensate for their late start in nutrient release. This study was conducted to assess the growth and yield of maize with fortified organic fertilizers, compared to performance with inorganic fertilization.

\section{MATERIALS AND METHODS}

The experiment was conducted on an Alfisol at the Institute of Agricultural Research and Training, Ibadan on latitude $7^{0} 22^{1 / 2}{ }^{\prime} \mathrm{N}$ and longitude $3^{0} 50^{1} 2^{\prime} \mathrm{E}$ in the degraded rainforest vegetation zone of Nigeria. The region is characterized by a bimodal rainfall pattern with a long rainy season, which usually starts in late March while the short rainy season extends from September to early November after a short dry spell in August. The soil of the experimental site was strongly leached, with low to medium humus content, deep red-clayed profile with top sandy texture (Table 1). Maize, cassava and legumes were the main crops in the experimental areas with little fertilizer application. The experiment was laid out in a randomized complete block design (RCBD) with three locational replicates having plot size of $3 \times 6 \mathrm{~m}$ with treatments: No Fertilizer (Control); Pacesetter Fertilizer $-2.5 \mathrm{t} \mathrm{ha}^{-1}+100 \mathrm{~kg} \mathrm{t}^{-1}$ Urea; Poultry Manure $-2.5 \mathrm{t} \mathrm{ha}^{-1}+100 \mathrm{~kg} \mathrm{t}^{-1}$ Urea; NPK $20-10-10$ at $400 \mathrm{Kg} \mathrm{ha}^{-1}$. The Pacesetter fertilizer was a commercial fertilizer from municipal waste and cow dung

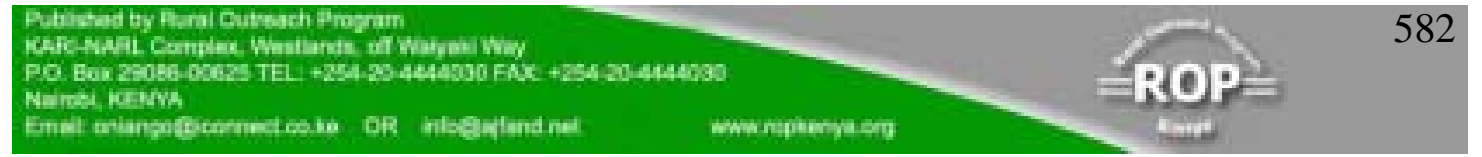


from an Abattoir. The Poultry manure was the droppings from chicken that had been left to decompose for about 200 days. Urea, at $100 \mathrm{~kg}$ was added to one tonne of the organic fertilizers to fortify the $\mathrm{N}$ contents. The nutrient composition of the organic fertilizers before addition of the Urea is presented in Table 1.The maize variety planted was SUWAN 1.The organic fertilizers were applied a week before planting. Inorganic fertilizer (NPK 20 -10-10) was applied 2 weeks after planting (WAP) by ringing around the maize plant. The plots were weeded manually whenever necessary throughout the experimental period. Maize was harvested fresh at 14WAP and was sun-dried to $14 \%$ moisture content. Growth and yield parameters such as plant height (cm); average leaf area per plant $\left(\mathrm{cm}^{2}\right)$; number of days to achieve $50 \%$ tasselling and dry grain yield $\left(\mathrm{t} \mathrm{ha}^{-1}\right)$ were recorded. The Analysis of Variance (ANOVA) procedure was carried out to determine the treatment effects. Mean values were separated using the Least Significant Difference (LSD) at 0.05 level of probability.

\section{RESULTS}

Fertilizer application had a significant effect on plant height. In the first year, application of poultry manure gave the tallest plants of $27 \mathrm{~cm}$ which was only significantly $(\mathrm{P}=0.05)$ taller than plants treated with inorganic fertilizer (NPK 20-1010) that had an average plant height of $22.8 \mathrm{~cm}$. Other plant heights were comparable (Fig.1).

\section{Figure 1: $\quad$ Effect of fertilizer type on maize average plant height $(\mathrm{cm})$}
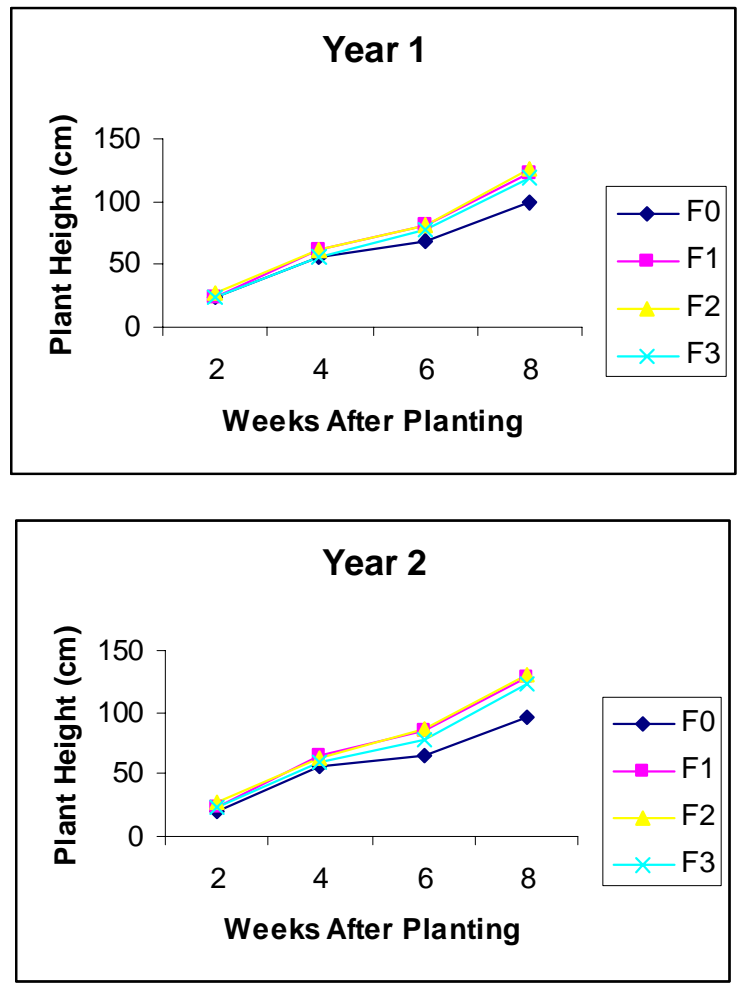

$\mathrm{F}_{\mathrm{O}^{--}}$No fertilizer: $\mathrm{F}_{1}$-- Pacesetter fertilizer;

$\mathrm{F}_{2}$-- poultry Manure; $\mathrm{F}_{3}-\mathrm{NPK} 20-10-10$ 
In the second year, plant heights from all the fertilized plots were comparable, with plants fertilized with poultry manure still giving significantly $(\mathrm{P}=0.05)$ taller plants of $27 \mathrm{~cm}$ than plants from the unfertilized plots that had plants $20 \mathrm{~cm}$ tall. This trend was maintained through the $4^{\text {th }}$ week to the $8^{\text {th }}$ week. All the fertilized plots had plants comparable in height, but were significantly taller than plants from the control plots (Fig.1).

Plant leaf areas were all similar at 2WAP in the first year but were significantly different as from $4 \mathrm{WAP}$, when poultry manure gave leaves with the highest leaf area of $228 \mathrm{~cm}^{2}$ which were comparable with leaves from plants fertilized with Pacesetter fertilizer that had a leaf area of $225 \mathrm{~cm}^{2}$.Inorganic fertilizer produced significantly smaller leaves (Fig.2).As from 6WAP, Pacesetter fertilizer gave leaves with the highest leaf area which was also comparable with leaf areas from poultry manure application. In the second year, leaf areas were significantly $(\mathrm{P}=0.05)$ different as from 2WAP.Poultry manure application gave leaves with the highest leaf area of $31 \mathrm{~cm}^{2}$ which was comparable with $30 \mathrm{~cm}^{2}$ leaves obtained with the Pacesetter fertilizer application.

Figure 2: $\quad$ Effect of fertilizer type on maize average leaf area $\left(\mathrm{cm}^{2}\right)$
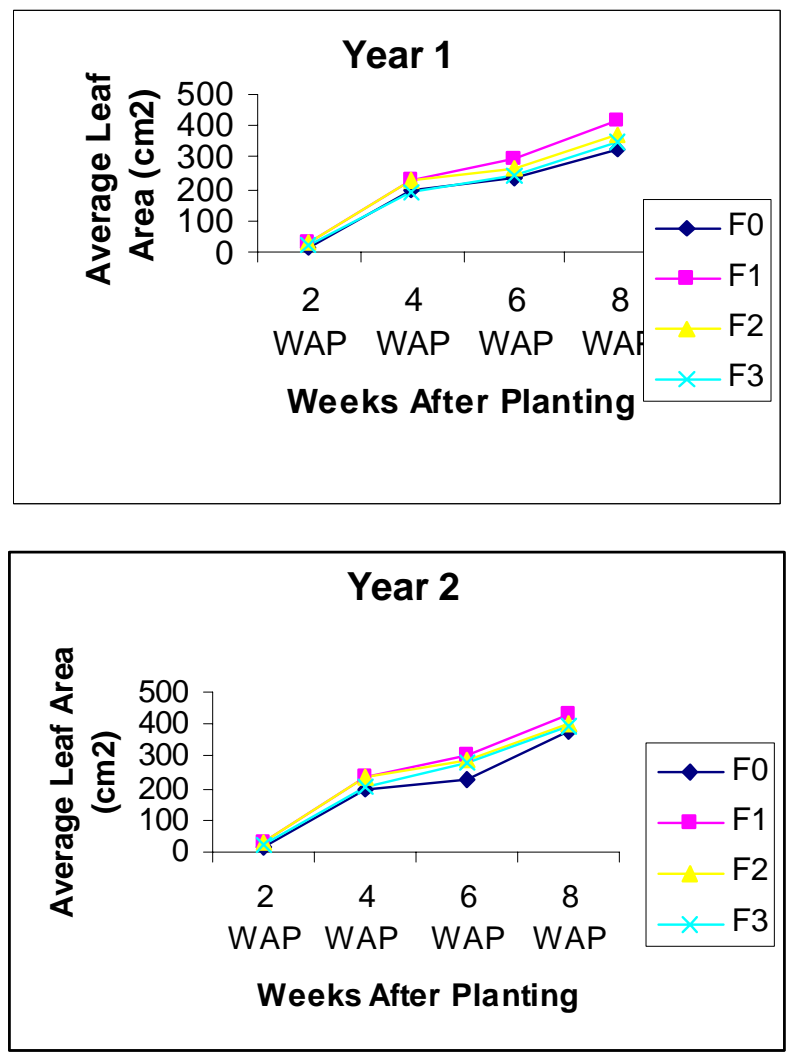

$F_{0^{--}}$No fertilizer: $F_{1^{--}}$Pacesetter fertilizer;

$F_{2}-$ - poultry manure; $F_{3}--$ NPK $20-10-10$ 
The Pacesetter fertilizer gave the widest leaves as from 6 WAP in the first year but in the second year, they gave the widest leaves as from 4 WAP. Plant leaf areas were, however, similar only from 6WAP. Inorganic fertilizer application generally gave leaves smaller than from poultry manure application (Fig.2). Plant growth assessment at harvest showed that plant heights were all comparable among the three fertilizer sources. Plant height from NPK fertilizer application was however not significantly $(\mathrm{P}=0.05)$ taller than from the unfertilized, control plots, in the first year. By the second year, however, they were also significantly taller than from the control plots (Table 2). Plants fertilized with inorganic NPK fertilizer generally tasselled significantly earlier than other treatments. It attained 50\% tasselling in 50days in the first year but in 49days in the second year. Poultry manure-fertilized plants tasselled in 52days and 51days, in the first and second years, respectively while it took 53 days in both years for the Pacesetter fertilizer to achieve 50\% tasselling.The unfertilized, control plots tasselled significantly much later. The crop attained 50\% tasselling in 56days in the first year but in 55days in the second year (Table 2).Ear heights were all similar in the first year but in the second year, ear height from poultry manure plots was only significantly $(\mathrm{P}=0.05)$ higher than from the control plots. Other ear heights were comparable (Table 2).

The dry grain yield was highest from poultry manure application. The Pacesetter fertilizer and the NPK fertilizer also gave comparable yields, although yields from Pacesetter fertilizer were higher (Table 4). Cob lengths among the various fertilizers were similar and were significantly $(\mathrm{P}=0.05)$ higher than from the control plots. The cobs were between 14 and $17 \mathrm{~cm}$ long with the fertilized plants while they were between 10 and $12 \mathrm{~cm}$ for the control plants. Average cob weight followed the same trend as cob length, ranging from 128 to $140 \mathrm{~g}$ for the fertilized plants while it ranged from 110 to $117 \mathrm{~g}$ for the unfertilized plants (Table 3). Average number of seeds per cob was highest from the Pacesetter fertilizer. It was followed by cobs from poultry manure application. The unfertilized plants had cobs with the smallest number of seeds. All the cobs were, however, comparable. Weights of 100 seeds were significantly $(\mathrm{P}=0.05)$ lower with the unfertilized plants. They were only comparable with seeds from the Pacesetter fertilizer in the first year alone. They were significantly different in the second year. All the fertilized plants had seeds with comparable weights in the two years (Table 3). The final soil $\mathrm{N}$ content was reduced with cropping, without fertilization. It was reduced from an initial $0.12 \%$ to $0.08 \%$. Fertilizing maize with fortified poultry manure increased the soil $\mathrm{N}$ to $0.17 \%$ and to $0.15 \%$ with NPK and with the Pacesetter fertilizers fortified with Urea (Table 4). Available $\mathrm{P}$ followed the same trend as soil $\mathrm{N}$, with poultry manure increasing the $\mathrm{P}$ content from an initial $6.09 \mathrm{ppm}$ to $6.20 \mathrm{ppm}$ while the Pacesetter fertilizer and the NPK fertilizer increased the available P to 6.15 and $6.11 \mathrm{ppm}$, respectively (Table 4). The potassium content was most increased with the Pacesetter fertilizer application. This was followed by the poultry manure application. Plants fertilized with inorganic NPK fertilizer just maintained the $\mathrm{K}$ content but the content was lowered from an initial 0.29 to $0.22 \mathrm{cmol} \mathrm{kg}^{-1}$ with no fertilizers. The Ca content was also increased with applications of both the organic fertilizer and poultry manure but was reduced with NPK fertilizer application. It was the same with the soil Mg content (Table 4).

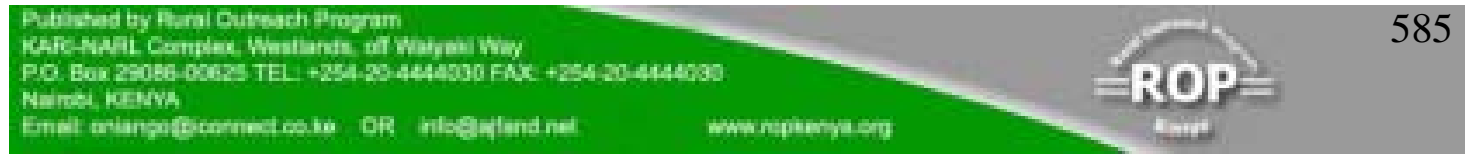




\section{DISCUSSION}

Maize growth was affected by an enriched organic fertilizer. The greater plant height and leaf area values recorded from the organic fertilizers, after 2 weeks of growth, relative to inorganic fertilizer application indicate that the added nitrogen, which had been applied to the field, 4 weeks earlier was available to the plants. However, nitrogen from the inorganic fertilizer, which was just applied, was not yet effective. Although the values were comparable at 2WAP in the first year, they were significantly different by the second year. This can be attributed to the residual effect of the organic fertilizers of the first year. Maize growth that was favoured by the enriched organic fertilizers as sole inorganic fertilization as from 4WAP is an indication that adequate nutrients, required to support early growth can be attained from organic fertilization, by enrichment with inorganic nutrients. Although growth performance with both organic fertilizers were comparable, it is worthy of note that the Pacesetter fertilizer (made from cow dung) was already fortified with some municipal waste before the addition of Urea in the experiment. On the other hand, the poultry manure was only fortified once. This shows that the cow dung will require greater fortification than poultry manure, to give a comparable level of performance. At maturity, maize growth was similar when cultivated with $400 \mathrm{~kg}$ N-P-K $20-10-10$ ha ${ }^{-1}$ compared with cultivation with just $2.5 \mathrm{t} \mathrm{ha}^{-1}$ cow dung or poultry manure + $100 \mathrm{~kg}$ Urea. Maize grain yield was significantly increased with fertilization. Organic fertilizers can be enriched with inorganic nitrogen to have maize yields similar to yields from plants fertilized with inorganic fertilizers. Plant nutrient use efficiency has been reportedly increased with combined organic and inorganic nutrient application.[10] Such responses have been reported on several crops. Adeniyan and Ojeniyi [8] have reported a higher yield of maize from a combined use of NPK fertilizer and poultry manure than from sole applications. Makinde et al. [9] have earlier reported that maize yields from a mixture of organic and inorganic fertilizer applications were significantly higher than yields from sole organic fertilizer application. They also found that organic fertilizer application did not benefit the yield of maize significantly. Murwira and Kirchmann [10] have observed that the nutrient use efficiency of a crop is increased through a combined application of organic manure and mineral fertilizer. Maize growth with complementary inorganic + organic fertilizers and with sole inorganic fertilizer treatment were comparable because nutrients seemed released early from the inorganic fertilizer and maize, being an aggressive feeder, was able to utilize it for its growth. Although the rate of application of inorganic nutrients was reduced in the combined use, complementation with nutrients from organic manure made comparable yields as from sole inorganic fertilizer application realizable. Chung et al. [11] have shown that application of organic manures with an adequate amount of chemical $\mathrm{N}$ fertilizer gave higher dry matter yield of maize. Satyanarayana et al. [12] have reported an optimum grain yield of rice with an application of $10 \mathrm{tha}^{-1}$ farmyard manure complemented with $120 \mathrm{~kg} \mathrm{~N}$ compared to sole manure and sole inorganic fertilizers. This was attributed to increased nutrient uptake and increased number of tillers and filled grains per panicle. Plant uptake of $\mathrm{N}, \mathrm{P}$ and $\mathrm{K}$ was reported to be at maximum with application of farmyard manure complemented with 120:60:45kg N: $\mathrm{P}_{2} \mathrm{O}_{5}: \mathrm{K}_{2} \mathrm{O}$ ha $^{-1}$. Bayu et al. [13]

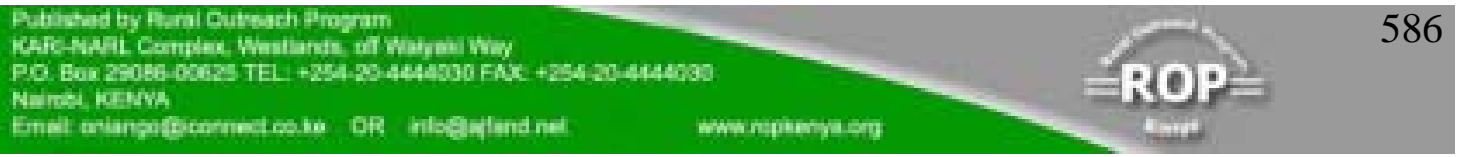


also reported a sorghum grain yield of $3590 \mathrm{~kg}$ with $15 \mathrm{t} \mathrm{ha}^{-1}$ manure and 3726 with $41 \mathrm{~kg} \mathrm{~N}+20 \mathrm{~kg} \mathrm{P} \mathrm{ha}^{-1}$ inorganic fertilizer but a yield of 3822 and $3997 \mathrm{~kg}$, respectively with 5 and $10 \mathrm{tha}^{-1}$ manure complemented with half rate of NP inorganic fertilizer. The root yield of sweet potato was reportedly increased by $27 \%$ with inorganic fertilizer, $47 \%$ by sole organic fertilizer but by $97 \%$ with organic manure complemented with inorganic fertilizer [14]. Poultry manure application gave a higher total yield and quality of Broccoli plants than cattle manure [7]. Padwick [15] has reported that many African soils show nutrient deficiency problems after a short period of cultivation, with $\mathrm{N}$ being most depleted. This seems to be dependent on the crop involved. Cassava was reported to deplete soil $\mathrm{N}$ by $78 \%$ without fertilization; by $83 \%$ with sole organic fertilizer but by $67 \%$ with an enriched organic fertilizer [16]. Ayoola [17], also reported the soil $\mathrm{N}$ to be depleted from $1.80 \mathrm{~g} \mathrm{~kg}^{-1}$ by $47 \%$ without fertilizer, $54 \%$ with inorganic fertilization but by $26 \%$ with an enriched organic fertilizer. This study has, however, shown that although the soil N, P and K contents were reduced by maize cropping, they are increased with fertilization. Soil $\mathrm{N}$ and $\mathrm{P}$ contents are increased more, with poultry manure than cow dung, showing the higher potentials of poultry manure for sustained longer cultivation. Poultry manure has been reported a better organic manure than other organic sources [18]. Pacesetter fertilizer, however, showed a higher potential for increasing soil $\mathrm{K}, \mathrm{Ca}$, and $\mathrm{Mg}$ contents. This is attributable to the higher intake of these nutrients by cattle animals from grasses, which are passed out through the faeces. The increases in the soil N,P and K contents after two years cropping is an indication that the NPK requirements of maize can be met by the use of an enriched manure as an alternative to inorganic fertilizers.

\section{CONCLUSION}

Use of high tonnages of organic manures, to achieve high maize yields can be combated with enriching the manure. One tonne stale poultry droppings can be fortified with $100 \mathrm{~kg}$ urea and applied at $2.5 \mathrm{t} \mathrm{ha}^{-1}$ to have maize yield comparable with the use of $400 \mathrm{~kg}$ NPK $20-10-10 \mathrm{ha}^{-1}$.

Use of cow dung to achieve a comparable yield as with 400kg NPK 20-10-10 ha $^{-1}$ requires fortification with equal weight of municipal waste and further fortification with $100 \mathrm{~kg}$ urea, to a tonne of the mixture.

After two years of application and cropping, enriched poultry manure increases soil $\mathrm{N}, \mathrm{P}$ and $\mathrm{K}$ contents by $41.7 \%, 1.8 \%$ and $20.7 \%$, respectively while fortified cow dung increases the nutrients by $25 \%, 0.33 \%$ and $3.4 \%$, respectively. 


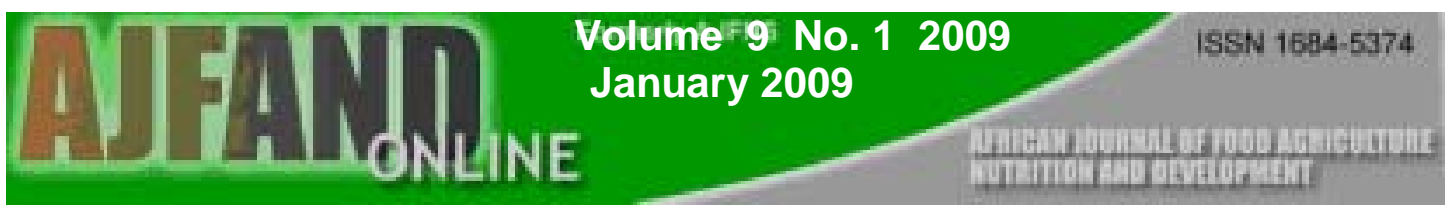

Table 1: Initial soil characteristics and chemical properties of organic manure

\begin{tabular}{|c|c|c|c|}
\hline Chemical Properties & Soil & $\begin{array}{c}\text { Pacesetter } \\
\text { Manure } \\
(\%)\end{array}$ & $\begin{array}{c}\text { Poultry Manure } \\
\qquad(\%)\end{array}$ \\
\hline $\mathrm{pH}$ & 6.7 & 7.6 & 6.0 \\
\hline Organic C & $1.18 \%$ & 6.08 & 12.45 \\
\hline Total-N & $0.12 \%$ & 0.61 & 2.57 \\
\hline Available P & $6.09 \mathrm{ppm}$ & 0.62 & 1.64 \\
\hline Exchangeable K & $0.29 \mathrm{Cmol} \mathrm{kg}^{-1}$ & 2.75 & 1.52 \\
\hline Exchangeable $\mathrm{Na}$ & 0.14 & 0.26 & 0.36 \\
\hline Exchangeable $\mathrm{Ca}$ & 3.35 & 3.50 & 5.27 \\
\hline Exchangeable Mg & 0.76 & 0.52 & 0.30 \\
\hline Exchangeable Acidity & 0.09 " & & \\
\hline CEC & 4.63 & & \\
\hline \multicolumn{4}{|l|}{ Physical properties } \\
\hline Sand & $79.2 \%$ & & \\
\hline Silt & $11.2 \%$ & & \\
\hline Clay & $9.6 \%$ & & \\
\hline
\end{tabular}




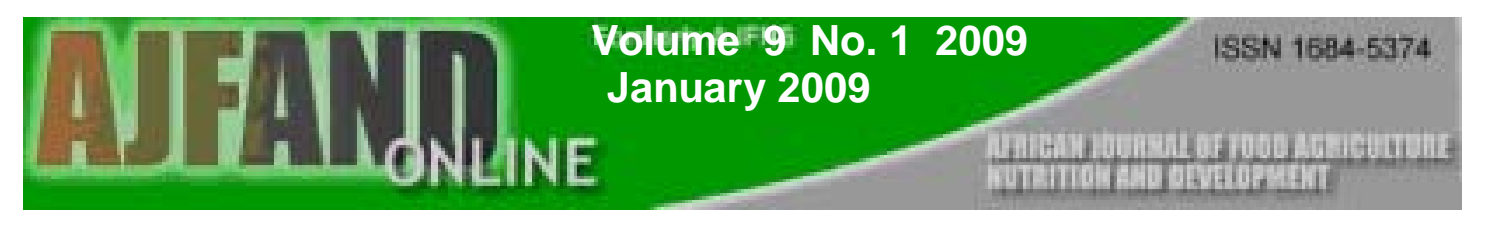

Table 2: $\quad$ Maize Growth Assessment at Harvest

\begin{tabular}{|c|c|c|c|c|c|c|}
\hline \multirow{2}{*}{} & \multicolumn{2}{|c|}{$\begin{array}{c}\text { Plant Height at Harvest } \\
(\mathrm{cm})\end{array}$} & \multicolumn{2}{c|}{$\begin{array}{c}\text { No. of days to 50\% } \\
\text { Tasselling }\end{array}$} & \multicolumn{2}{c|}{ Ear Height (cm) } \\
\cline { 2 - 7 } & 2005 & 2006 & 2005 & 2006 & 2005 & 2006 \\
\hline No fertilizer & 240.1 & 227.5 & 56 & 55 & 80.5 & 70.41 \\
\hline Pacesetter fertilizer & 247.0 & 258.2 & 53 & 53 & 68.83 & 75.20 \\
\hline Poultry manure & 255.2 & 262.4 & 52 & 51 & 77.67 & 78.74 \\
\hline NPK fertilizer & 250.3 & 255.2 & 50 & 49 & 70.17 & 72.35 \\
\hline LSD(0.05) & 14.61 & 10.82 & 1.84 & 2.04 & 14.18 & 5.30 \\
\hline
\end{tabular}

Table 3: $\quad$ Maize yield and yield components

\begin{tabular}{|c|c|c|c|c|c|c|c|c|c|c|}
\hline & \multicolumn{2}{|c|}{ Grain Yield (t/ha) } & \multicolumn{2}{|c|}{ Cob Length $(\mathrm{cm})$} & \multicolumn{2}{|c|}{$\begin{array}{c}\text { Cob Weight } \\
(\mathrm{g})\end{array}$} & \multicolumn{2}{|c|}{$\begin{array}{l}\text { Av. No. of } \\
\text { Seeds/Cob }\end{array}$} & \multicolumn{2}{|c|}{$\begin{array}{c}\text { Weight of } 100 \\
\text { Seeds (g) }\end{array}$} \\
\hline & 2005 & 2006 & 2005 & 2006 & 2005 & 2006 & 2005 & 2006 & 2005 & 2006 \\
\hline No fertilizer & 2.94 & 2.01 & 11.90 & 10.40 & 116.60 & 110.50 & 349.3 & 321.4 & 20.60 & 17.50 \\
\hline $\begin{array}{l}\text { Pacesetter } \\
\text { fertilizer }\end{array}$ & 3.72 & 3.85 & 15.17 & 16.75 & 133.72 & 140.84 & 434.3 & 443.7 & 24.97 & 26.06 \\
\hline $\begin{array}{l}\text { Poultry } \\
\text { manure }\end{array}$ & 4.06 & 3.92 & 14.37 & 17.20 & 128.11 & 132.31 & 428.7 & 430.4 & 28.97 & 27.10 \\
\hline $\begin{array}{c}\text { NPK } \\
\text { fertilizer }\end{array}$ & 3.67 & 3.73 & 14.30 & 15.35 & 127.37 & 131.20 & 392.0 & 401.8 & 23.94 & 24.80 \\
\hline $\operatorname{LSD}(0.05)$ & 1.38 & 1.03 & 2.01 & 3.18 & 7.51 & 11.47 & 137.51 & $\begin{array}{l}141.7 \\
5\end{array}$ & 5.68 & 7.06 \\
\hline
\end{tabular}


Table 4: $\quad$ Soil nutrient changes with different organic fertilizers

\begin{tabular}{|c|c|c|c|c|c|c|}
\hline & $\begin{array}{c}\mathrm{N} \\
\%\end{array}$ & $\begin{array}{c}\mathrm{P} \\
(\mathrm{ppm})\end{array}$ & $\begin{array}{c}\mathrm{K} \\
(\mathrm{CmolKg})\end{array}$ & $\begin{array}{c}\text { Organic } \\
\mathrm{C} \\
\%\end{array}$ & $\begin{array}{c}\mathrm{Ca} \\
\left(\mathrm{CmolKg}^{-}\right. \\
{ }^{-}\end{array}$ & $\begin{array}{c}\mathrm{Mg} \\
\left(\mathrm{CmolKg}^{-}\right. \\
1)\end{array}$ \\
\hline $\begin{array}{c}\text { Initial } \\
\text { No } \\
\text { fertilizer }\end{array}$ & 0.12 & 6.09 & 0.29 & 1.18 & 3.35 & 0.76 \\
\hline $\begin{array}{c}\text { Pacesetter } \\
\text { fertilizer }\end{array}$ & 0.15 & 6.15 & 0.47 & 1.42 & 3.42 & 0.82 \\
\hline $\begin{array}{c}\text { Poultry } \\
\text { manure }\end{array}$ & 0.17 & 6.20 & 0.35 & 2.15 & 3.38 & 0.80 \\
\hline $\begin{array}{c}\text { NPK } \\
\text { fertilizer }\end{array}$ & 0.15 & 6.11 & 0.30 & 1.12 & 2.87 & 0.71 \\
\hline LSD(0.05) & 0.055 & 0.157 & 0.107 & 0.964 & 0.742 & 0.085 \\
\hline
\end{tabular}




\section{REFERENCES}

1. Kang BT and ASR Juo Management of low- activity clay soils in Tropical Africa for food crop production. Pp.129-133 in: Terry E.R., K.A. Oduro and F Caveness (Eds). Tropical Root Crops: Research Strategies for the 1980s. Ottawa, Ontario, IDRC. 1980.

2. Sharma AR and BN Mittra. Effect of different rates of application of organic and nitrogen fertilizers in a rice-based cropping system. J. Agr. Sci. (Camb.) 1991; 117: 313-318.

3. Abou El-Magd MM, Hoda Mohammed A and ZF Fawzy Relationships, growth, yield of broccoli with increasing N, P or K ratio in a mixture of NPK fertilizers. Annl. Agr. Sci. Moshtohor. 2005; 43 (2): 791-805.

4. Seifritz W Alternative and renewable sources of energy in optimizing yields: The role of Fertilizers. In: Proc. of $12^{\text {th }}$ IPI Congress. 1982:153-163.

5. Belay A, Classens AS, Wehner FC and JM De Beer Influence of residual manure on selected nutrient elements and microbial composition of soil under long-term crop rotation. South Afr. J. Plant and Soil 2001;18: 1-6.

6. EI - Shakweer MHA, EI - Sayed EA and MSA Ewees Soil and plant analysis as a guide for interpretation of the improvement efficiency of organic conditioners added to different soils in Egypt. Commun. Soil Sci. Plant Anal. 1998; 29: 2067-2088.

7. Abou El-Magd MA, El-Bassiony M and ZF Fawzy. Effect of organic manure with or without chemical fertilizers on growth, yield and quality of some varieties of Broccoli plants. J. Appl. Sci. Res. 2006;2(10):791-798.

8. Adeniyan ON and SO Ojeniyi Effect of poultry manure, NPK 15-15-15 and combination of their reduced levels on maize growth and soil chemical properties. Nig. J. of Soil Sci. 2005; 15: 34-41.

9. Makinde EA, Agboola AA and FI Oluwatoyinbo The effects of organic and inorganic fertilizers on the growth and yield of maize in a maize/melon intercrop. Moor J. Agr. Res. 2001 2: 15-20.

10. Murwira HK and H Kirchman. Carbon and Nitrogen Mineralization of cattle manures subjected to different treatments in Zimbabwean and Swedish soils. In: Mulongoy K. and R. Merck (Eds). Soil Organic matter dynamics and sustainability of tropical Agriculture. 1993.

11. Chung RS, Wang CH, Wang CW and YP Wang Influence of organic matter and inorganic fertilizer on the growth and Nitrogen accumulation of Corn plants. J. Plant Nutr. 2000; 23: (3):297-311.

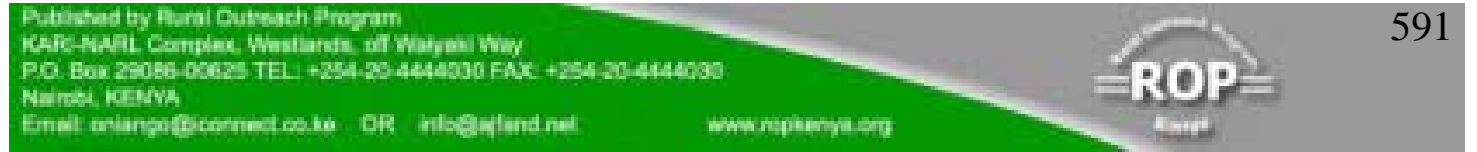


12. Satyanarayana VM, Vera Prasad PV, Murphy VRK and KJ Boots. Influence of integrated use of farmyard manure and inorganic fertilizer on yield and yield components of irrigated lowland rice. J. Plant Nutr. 2002; 25(10):2081 -2090 .

13. Bayu W, Rethman NFG, Hammes PS and G Alemu Effects of Farmyard Manure and Inorganic Fertilizers on Sorghum Growth, Yield and Nitrogen use in a Semi-arid area of Ethiopia. J. Plant Nutr. 2006; 29(2):391-407.

14. Osundare B. Effects of fertilizer types and different companion crops on the performance of sweet potato. Moor J. Agr. Res. 2004; 5(2): 88-94.

15. Padwick GW Fifty years of experiment II. The maintenance of soil fertility in tropical Africa: A review. Exptal Agr. 1983; 19: 293-310.

16. Makinde EA and AA Agboola Soil nutrient changes with fertilizer type in a cassava-based cropping system. J. Plant Nutr. 2002; 23(10):2303 - 2313.

17. Ayoola OT Effects of fertilizer treatment on soil chemical properties and crop yield in a cassava-based cropping system. J. Appl. Sci. Res. 2006;2(12): 11121116.

18. Ano AO and JA Agwu Effect of animal manures on selected soil chemical properties. Nigerian Journal of Soil Science 2005; 15: 14-19. 